\title{
KETERSEDIAAN CABAI MERAH (Capsicum annuum L.) DALAM MENOPANG KETAHANAN PANGAN DI KABUPATEN PATI
}

\section{AVAILABILITY OF CHILI PEPPER TO SUPPORT FOOD SECURITY IN PATI REGENCY}

\author{
Sutrisno \\ Kantor Penelitian dan Pengembangan Kabupaten Pati \\ Email: trisno_1201@yahoo.com
}

Naskah Masuk: 28 Maret 2015 Naskah Revisi: 7 April $2015 \quad$ Naskah Diterima: 21 April 2015

\begin{abstract}
Chili peppers contain several nutrition and vitamins. This research aimed to analyze the availability and price movements of chili pepper in Pati Regency. It used descriptive approach and data were sourced primary and secondary. Data were analyzed using descriptive analysis and statistical test. The results of research were: the availability of chili pepper in the last five years was 2,150 ton/year, while the need of chili pepper was 19,866 ton/year, so that the amount of insufficient supply of chili pepper was 17,716 ton. It proved that Pati Regency has not been yet to achieve food security for chili pepper. There was unpredictable price fluctuation of chili pepper from January to December 2014. At the beginning of the year the price of chili pepper was $R p 26,975 / \mathrm{kg}$, in the midyear, it was Rp 8,276/kg, while in the end in the end of the year, it was $53,901 / \mathrm{kg}$.
\end{abstract}

Keywords: availability, chili pepper, food security

\begin{abstract}
ABSTRAK
Cabai memiliki banyak kandungan gizi dan vitamin. Penelitian ini bertujuan untuk menganalisis ketersediaan dan perkembangan harga cabai merah di Kabupaten Pati. Metode penelitian menggunakan deskriptif, dengan sumber data primer dan sekunder. Analisis data dengan cara deskriptif dan analisis statistik. Hasil penelitian menunjukkan bahwa ketersediaan cabai merah rata-rata 5 tahun terakhir 2.150 ton, kebutuhan cabai merah 19.866 ton sehingga terjadi minus 17.716 ton, oleh sebab itu Kabupaten Pati belum mencapai ketahanan pangan dibidang cabai merah, dan perkembangan harga cabai selama tahun 2014 (Januari-Desember) mengalami fluktuasi yang sangat signifikan sehingga sulit diprediksi, hal ini terlihat pada awal tahun harganya Rp 26.975/kg, pertengahan tahun Rp 8.276/kg dan pada akhir tahun mencapai Rp 53.901/kg.
\end{abstract}

Kata kunci: cabai merah, ketahanan pangan, ketersediaan

\section{PENDAHULUAN}

Kecukupan pangan dan gizi merupakan salah satu faktor yang sangat penting dalam menentukan kualitas sumber daya manusia. Di sisi lain, kualitas sumber daya manusia juga sangat menentukan dalam peningkatan produktivitas dan daya saing bangsa dalam era persaingan global seperti saat ini. Oleh karena itu, ketahanan pangan selalu menjadi isu strategis dan fundamental dalam perkembangan pembangunan yang berkesinambungan (Sutrisno, 2014). 
Ketahanan pangan adalah kondisi terpenuhinya pangan bagi negara sampai dengan perseorangan yang tercermin dari tersedianya pangan yang cukup, baik jumlah maupun mutunya, aman, beragam, bergizi, merata, dan terjangkau serta tidak bertentangan dengan agama, keyakinan, dan budaya masyarakat untuk dapat hidup sehat, aktif, dan produktif secara berkelanjutan (UU No 18 Tahun 2012).

Peningkatan jumlah penduduk menjadi salah satu permasalahan di Kabupaten Pati Provinsi Jawa Tengah dalam hal pemenuhan kebutuhan pangan termasuk cabai merah. Peningkatan jumlah penduduk berkorelasi positif dengan peningkatan pemenuhan kebutuhan pangan tersebut. Mengacu pada pertumbuhan penduduk Kabupaten Pati pada 2 (dua) tahun terakhir (2012 dan 2013) masing-masing yaitu 1.210 .025 jiwa dan 1.218.016 jiwa dengan pertumbuhan 0,66\% (BPS Kab. Pati, 2014). Kondisi ini mengindikasikan bahwa kebutuhan terhadap pangan semakin meningkat dari tahun ke tahun. Sementara luas lahan sawah berdasarkan pengairan $59.332 \mathrm{Ha}$, dengan perincian: pengairan teknis $17.887 \mathrm{Ha}$; pengairan setengah teknis $8.900 \mathrm{Ha}$; pengairan sederhana 7.165 Ha; pengairan desa 2.758 $\mathrm{Ha}$; sawah tadah hujan $22.376 \mathrm{Ha}$; dan lainnya $245 \mathrm{Ha}$ (BPS Kab. Pati, 2012).

Tanaman cabai merah (Capsicum annuum L.) adalah tanaman perdu dengan rasa buah pedas yang disebabkan oleh kandungan capsaicin. Secara umum cabai memiliki banyak kandungan gizi dan vitamin, diantaranya kalori, protein, lemak, kabohidrat, kalsium, vitamin A, B1, dan vitamin C (BPTP Jateng, 2010).

Produksi cabai merah nasional selama periode 2008-2012 cenderung terus meningkat dengan laju pertumbuhan rata-rata $9,79 \%$ per tahun. Pada tahun 2012 produksi cabai merah mencapai sekitar 1,66 juta ton. Sumber pertumbuhan produksi cabai adalah pertumbuhan luas panen yang juga cenderung meningkat dengan laju ratarata $2,97 \%$ per tahun dan peningkatan produktivitas rata-rata $6,83 \%$ per tahun. Dengan demikian, selama periode tersebut pertumbuhan produksi cabai hampir $70 \%$ disokong oleh pertumbuhan produktivitas dan $30 \%$ dari pertumbuhan luas panen. Daerah-daerah produsen cabai merah di wilayah Jawa sebagai pusat produksi cabai terutama adalah Jawa Timur $(37,7 \%)$, disusul oleh Jawa Barat $(32,0 \%)$ dan Jawa Tengah $(23,6 \%)$. Meskipun produksi cabai rata-rata per tahun meningkat sangat cepat, harga cabai seringkali berfluktuasi karena produksi bersifat musiman, dimana harga turun pada musim panen dan harga naik di luar musim panen. Untuk stabilisasi pasokan dan harga cabai, perlu dilakukan perbaikan manajemen serta teknologi produksi (Bappenas, 2013). Selanjutnya menurut Bappenas (2013) konsumsi cabai tahun 2012 mencapai 769.550 ton dengan produksi 1.656 .620 ton sehingga terjadi surplus 887.060 ton. Namun fluktuasi harga cabai dan tingginya harga cabai pada saat-saat tertentu masih tetap menjadi permasalahan. Hal ini disebabkan distribusi pasokan yang belum bisa stabil menurut waktu dan gangguan transportasi dari pusat produsen ke lokasi konsumen misalnya karena banjir dan sebagainya. Sementara produksi cabai merah di Kabupaten Pati tahun 2013 baru mencapai 1.839 ton dengan luas panen $344 \mathrm{Ha}$, kebutuhan cabai merah mencapai 20.133 ton sehingga masih mengalami minus 
sebesar 18.294 ton (Sutrisno, 2014). Kekurangan cabai merah tersebut sebagian besar dipasok dari Kabupeten Rembang dan Jawa Timur, sehingga Kabupaten Pati belum mencapai ketahanan pangan di bidang komoditas cabai merah.

Kondisi geografis dan tingkat kesesuaian lahan pertanian Kabupaten Pati menunjukkan adanya potensi yang cukup besar untuk pengembangan cabai merah sebagai produk pertanian pangan dan sumber ketersediaan pangan nabati. Hal ini terlihat pada luas panen cabai merah rata-rata dalam 5 (lima) tahun terakhir (2008-2011) sebesar $357 \mathrm{Ha}$ (Sutrisno, 2013). Luas lahan dan kesuburan tanah Kabupaten Pati ternyata belum dapat dimanfaatkan secara optimal untuk membangun ketahanan pangan dan perekonomian rakyat pedesaan (Sutrisno, 2014). Hal inilah yang menarik perhatian penulis untuk meneliti ketersediaan komoditas cabai merah dalam menopang ketahanan pangan di Kabupaten Pati, dengan tujuan untuk menganalisis ketersediaan dan perkembangan harga cabai merah di Kabupaten Pati.

\section{KAJIAN PUSTAKA}

\section{Cabai Merah (Capsicum annuum L.)}

Tanaman cabai (Capsicum annum L.) berasal dari dunia tropika dan subtropika Benua Amerika, khususnya Colombia, Amerika Selatan, dan terus menyebar ke Amerika Latin. Bukti budidaya cabai pertama kali ditemukan dalam tapak galian sejarah Peru dan sisaan biji yang telah berumur lebih dari 5000 tahun SM di dalam gua di Tehuacan, Meksiko. Menurut Dermawan dalam Nurfalach dkk (2010) menyebutkan bahwa penyebaran cabai keseluruh dunia termasuk negara-negara di Asia, seperti
Indonesia dilakukan oleh pedagang Spanyol dan Portugis.

Cabai atau lombok termasuk dalam suku terong-terongan (Solanaceae) dan merupakan tanaman yang mudah ditanam di dataran rendah ataupun di dataran tinggi. Tanaman cabai banyak mengandung vitamin A dan vitamin C serta mengandung minyak atsiri capsaicin, yang menyebabkan rasa pedas dan memberikan kehangatan panas bila digunakan untuk rempah-rempah (bumbu dapur). Cabai dapat ditanam dengan mudah sehingga bisa dipakai untuk kebutuhan sehari-hari tanpa harus membelinya di pasar (Harpenas, 2010).

Tanaman cabai membutuhkan iklim yang cocok untuk pertumbuhannya agar dapat mencapai produktivitas yang tinggi. Iklim atau suhu yang ideal untuk budidaya cabai adalah $24^{\circ}-28^{\circ} \mathrm{C}$. Pada suhu tertentu seperti $15^{\circ} \mathrm{C}$ dan lebih dari $32^{\circ} \mathrm{C}$ akan menghasilkan buah cabai yang kurang baik. Pertumbuhan akan terhambat jika suhu harian di areal budidaya terlalu dingin. Tjahjadi (1991) mengatakan bahwa tanaman cabai dapat tumbuh pada musim kemarau apabila dengan pengairan yang cukup dan teratur.

Masa panen cabai berkisar antara 23 bulan setelah pemanenan perdana. Lamanya panen cabai berbeda-beda tergantung varietas cabai yang ditanam dan kondisi tanamannya. Pemanenan cabai sebaiknya dilakukan secara serentak dalam satu hamparan dan dilakukan pada kondisi buah cabai sudah tidak basah karena embun. Untuk menjaga kualitas buah, tempat hasil panen buah sehat harus dipisahkan dengan tempat untuk buah sakit. Dengan demikian tidak terjadi penularan buah sakit ke buah sehat selama pengangkutan dan penyimpanan. Buah cabai hasil panen setelah terkumpul selanjutnya dipilah-pilah (sortasi) antara buah yang bagus dan cacat. Pengkelasan 
buah (grading) dilakukan sesuai keperluan pembeli, setelah itu dikemas menurut keperluan. Pengemasan cabai untuk pasar lokal, pasar swalayan atau rumah makan akan berbeda-beda dalam pengemasannya. Misalnya dengan menggunakan karung plastik berlubang, kardus rokok, atau plastik khusus. Pengkelasan buah cabai dan pengemasannya untuk ekspor akan berbeda pula penanganannya (BPTP Jawa Tengah, 2010).

\section{Ketahanan Pangan}

Dari perspektif sejarah istilah ketahanan pangan (food security) muncul dan dibangkitkan karena kejadian krisis pangan dan kelaparan. Istilah ketahanan pangan dalam kebijakan pangan dunia pertama kali digunakan pada tahun 1971 oleh PBB untuk membebaskan dunia terutama negara-negara berkembang dari krisis produksi dan suplai makanan pokok. Fokus ketahanan pangan pada masa itu menitikberatkan pada pemenuhan kebutuhan pokok dan membebaskan daerah dari krisis pangan. Hal ini terlihat dari definisi ketahanan pangan oleh PBB sebagai berikut: food security is availability to avoid acute food shortages in the event of wide spread coop vailure or other disaster (Syarief dkk, 1999).

Selanjutnya definisi tersebut disempurnakan pada Internasional Conference of Nutrition tahun 1992 yang disepakati oleh pimpinan negara anggota PBB sebagai berikut: tersedianya pangan yang memenuhi kebutuhan setiap orang baik dalam jumlah dan mutu pada setiap saat untuk hidup sehat, aktif dan produktif. Di Indonesia, secara formal dalam dokumen perencanaan pembangunan nasional, istilah kebijakan dan program ketahanan pangan dimulai sejak tahun 1992 (Repelita VI) yang definisi formalnya dicantumkan dalam UU No. 18 Tahun 2012 tentang Pangan yang menyebutkan bahwa Ketahanan Pangan adalah kondisi terpenuhinya pangan bagi negara sampai dengan perseorangan, yang tercermin dari tersedianya pangan yang cukup, baik jumlah maupun mutunya, aman, beragam, bergizi, merata, dan terjangkau serta tidak bertentangan dengan agama, keyakinan, dan budaya masyarakat, untuk dapat hidup sehat, aktif, dan produktif secara berkelanjutan. Dengan demikian, ketahanan pangan dihasilkan oleh suatu sistem ketahanan pangan yang terdiri tiga subsistem, yaitu: 1) Ketersediaan pangan dalam jumlah dan jenis yang cukup untuk seluruh masyarakat; 2) Distribusi pangan yang lancar dan merata; dan 3) Keterjangkauan pangan setiap individu yang memenuhi kecukupan gizi dan kaidah kesehatan. Permasalahan dalam mencapai ketahanan pangan adalah ketidakseimbangan antara ketersediaan dengan keterjangkauan. Selanjutnya PP No. 68 Tahun 2002 menyebutkan bahwa Ketahanan Pangan adalah kondisi terpenuhinya pangan bagi rumah tangga yang tercermin dari tersedianya pangan yang cukup, baik jumlah maupun mutunya, aman, merata dan terjangkau. Sementara, ketersediaan pangan adalah tersedianya pangan dari hasil produksi dalam negeri dan/atau sumber lain.

\section{METODE PENELITIAN}

Penelitian ini menggunakan metode deskriptif. Menurut Nasir (2003) metode ini bertujuan untuk membuat deskripsi, gambaran atau lukisan secara sistematis, faktual dan akurat mengenai fakta-fakta, sifat-sifat serta hubungan antar fenomena yang diselidiki. Penelitian ini juga menggunakan pendekatan explanatory research yang bertujuan untuk menjelaskan hubungan antara dua atau lebih gejala atau variabel (Leedy and Ormrod, 2005). Faktor-faktor yang menjadi objek penelitian meliputi ketersediaan, kebutuhan, pertumbuhan, model rantai pasokan dan pemasaran, 
harga dan prediksi harga cabai di Kabupaten Pati.

Data primer diperoleh dari observasi/pengamatan dan wawancara dengan para narasumber (petani cabai merah, petugas Dispertanak, PPL, pedagang), sedangkan data sekunder diperoleh dari dokumen yang relevan.

Data yang telah terkumpul kemudian dianalisis dengan menggunakan cara deskriptif dan analisis statistik:

1. Untuk menghitung tingkat pengembangan komoditas pangan dikaitkan dengan kebutuhan/ permintaan pangan diambilkan dari data sekunder dan akan dianalisis dengan trend terkait dengan produksi/ketersediaan pangan cabai merah, kebutuhan dan penduduk. Rumus trend yang digunakan sesuai petunjuk Ibrahim (2003) sebagai berikut:

$\mathrm{Y}=\mathrm{a}+\mathrm{bX}$

Keterangan:

$\mathrm{Y}=$ nilai yang diperkirakan (produksi cabai merah)

$\mathrm{a}, \mathrm{b}=$ konstanta

$\mathrm{X}=$ tahun
2. Untuk menghitung pertumbuhan produksi cabai merah (data di ambil dari data sekunder) digunakan rumus sebagai berikut:

$t=\frac{t h_{t}-t h_{t-1}}{t h_{t-1}} \times 100 \%$

Keterangan:

$\mathrm{t}=$ pertumbuhan tahun

$\mathrm{th}_{\mathrm{t}} \quad=$ tahun riil sekarang

$\mathrm{th}_{\mathrm{t}-1}=$ tahun riil sebelum

3. Untuk menghitung prediksi harga cabai (data sekunder), digunakan regresi dengan persamaan sebagai berikut:

$\mathrm{Y}=\mathrm{a}+\mathrm{b} \mathrm{X}$

Keterangan:

$\mathrm{Y}=$ harga cabai

$\mathrm{a}, \mathrm{b}=$ konstanta

$\mathrm{X}=$ bulan

\section{HASIL DAN PEMBAHASAN}

\section{Ketersediaan Cabai Merah}

Ketersediaan

dan

trend perkembangan produksi cabai merah ratarata 5 (lima) tahun terakhir secara rinci dapat dilihat pada Tabel 1 .

Tabel 1.

Ketersediaan Cabai Merah

\begin{tabular}{|c|c|c|c|c|c|}
\hline Tahun & $\begin{array}{l}\text { Luas Panen } \\
\text { (Ha) }\end{array}$ & $\begin{array}{l}\text { Produksi } \\
\text { (ton) }\end{array}$ & Penduduk & $\begin{array}{c}\text { Kebutuhan (Ton) } \\
\left.16,529 \mathrm{~kg} / \mathrm{kapita} / \mathrm{th}^{*}\right)\end{array}$ & $\begin{array}{l}\text { Keterangan } \\
\text { (Ton) }\end{array}$ \\
\hline (1) & (2) & (3) & (4) & (5) & $(3)-(5)$ \\
\hline 2009 & 444 & 2.740 & 1.190 .993 & 19.686 & -16.946 \\
\hline 2010 & 305 & 1.595 & 1.194 .501 & 19.744 & -18.149 \\
\hline 2011 & 325 & 2.664 & 1.198 .529 & 19.810 & -17.146 \\
\hline 2012 & 358 & 1.914 & 1.207 .399 & 19.957 & -18.043 \\
\hline 2013 & 344 & 1.839 & 1.218 .016 & 20.133 & -18.294 \\
\hline Rata2 & 355 & 2.150 & 1.201.888 & 19.866 & -17.716 \\
\hline \multicolumn{2}{|c|}{ Pertumbuhan $(\%)$} & \multicolumn{4}{|l|}{$-4,63$} \\
\hline \multicolumn{2}{|c|}{ Coefficients } & \multicolumn{4}{|c|}{$Y=300381.7-148.3$} \\
\hline \multicolumn{2}{|c|}{ Trend } & \multicolumn{4}{|l|}{-148} \\
\hline
\end{tabular}

Sumber: BPS Kab. Pati (2010, 2011, 2012, 2013, 2014), *) Susenas (2012). 
Luas panen cabai merah terjadi secara fluktuatif. Luas panen cabai merah rata-rata dalam 5 tahun terakhir mencapai $355 \mathrm{Ha}$ dengan pertumbuhan minus $4,63 \%$. Luas panen cabai merah ini akan mempengaruhi produksi cabai merah di Kabupaten Pati. Luas panen cabai merah terluas terjadi pada tahun 2009 yaitu 444 Ha. Hal ini diduga kondisi iklim pada saat itu cukup kondusif, serangan penyakit tanaman cabai merah relatif dapat dikendalikan dan petani mulai tertarik pada komoditas ini.

Produksi cabai merah juga terjadi fluktuatif, rata-rata produksi cabai merah selama 5 tahun terakhir mencapai 2.150 ton. Cabai merah untuk konsumsi di Kabupaten Pati sebesar 19.866 ton sehingga kekurangan cabai merah sebesar 17.716 ton. Kekurangan ini dipasok dari luar daerah seperti Rembang dan sebagian Jawa Timur. Artinya Kabupaten Pati belum mencapai ketahanan pangan dibidang komoditas cabai merah. Sedangkan trend (kecenderungan) perkembangan produksi cabai merah di Kabupaten Pati selama 5 tahun terakhir menunjukkan angka negatif 148, artinya produksi cabai merah terjadi kecenderungan menurun sebesar 148 ton. Model rantai pasokan dan pemasaran cabai merah dapat dilihat pada Gambar 1 .

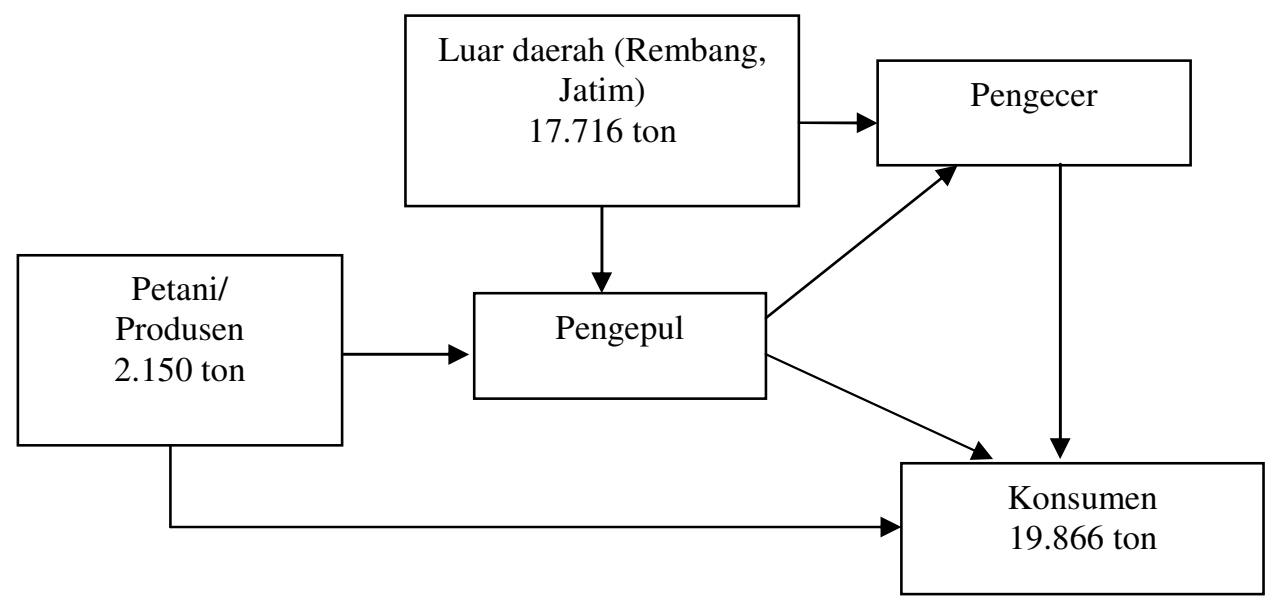

Gambar 1.

Model Rantai Pasokan dan Pemasaran Cabai di Kabupaten Pati Sumber: Pengolahan Data (2014)

\section{Perkembangan Harga Cabai}

Harga cabai selama 12 bulan (Januari-Desember 2014) mengalami fluktuasi yang sulit diprediksi. Harga tertinggi berada di bulan Desember 2014 yaitu Rp53.901/kg dengan pertumbuhan minus $16,41 \%$. Hal ini terjadi karena pada bulan tersebut permintaan banyak sementara persediaan cabai menipis karena belum masa panen, sehingga wajar jika harga naik jika dibanding dengan bulan-bulan lainnya. Sedangkan harga terendah berada di bulan Agustus yaitu Rp7.274/kg dengan pertumbuhan minus $3,19 \%$. Hal ini terjadi karena pada bulan tersebut persediaan cabai sudah lebih dari cukup karena terjadi masa panen cabai. Pertumbuhan harga cabai selama Bulan Januari-Desember 2014) secara rinci dapat dilihat pada Tabel 2. 
Tabel 2.

Pertumbuhan Harga Cabai

\begin{tabular}{ccc}
\hline Bulan & $\begin{array}{c}\text { Harga } \\
(\mathbf{R p} / \mathbf{k g})\end{array}$ & $\begin{array}{c}\text { Pertumbuhan } \\
(\mathbf{\%})\end{array}$ \\
\hline Januari & 26.975 & $-12,99$ \\
Februari & 23.472 & $-20,39$ \\
Maret & 18.687 & $-32,22$ \\
April & 12.666 & $-25,47$ \\
Mei & 9.440 & $-12,33$ \\
Juni & 8.276 & $-9,21$ \\
Juli & 7.514 & $-3,19$ \\
Agustus & 7.274 & 42,19 \\
September & 10.343 & 130,87 \\
Oktober & 23.879 & $-47,00$ \\
Nopember & 45.055 & $-16,41$ \\
\hline Desember & 53.901 & \\
\hline Jumlah & $\mathbf{1 4 8 . 5 2 6}$ & $\mathbf{- 0 , 5 1}$ \\
\hline Rata-rata & $\mathbf{1 2 . 3 7 7}$ & $\mathbf{0 , 1 8}$ \\
\hline $\boldsymbol{R}$ Square & & \\
\hline Coefficients & $\mathbf{9 0 8 0 , 2 7 3 + 1 7 7 5 , 8 8 1 ( 1 3 ) = 3 2 1 6 7}$ \\
\hline
\end{tabular}

Sumber: Pengolahan Data (2014).

Menggunakan analisis regresi dapat diprediksi harga cabai pada bulan ke-13 (Januari 2015), yaitu Rp32.167/kg. $R$ Square sebesar 0,18 , angka ini menjelaskan bahwa $18 \%$ keragaan data diterangkan oleh persamaan regresi tersebut, sedangkan sisanya $82 \%$ dipengaruhi oleh faktor-faktor lain di luar model, artinya masih banyak faktor-faktor yang mempengaruhi fluktuasi harga cabai, diantaranya adalah persediaan atau produksi cabai yang belum memenuhi kebutuhan.

\section{KESIMPULAN DAN SARAN}

\section{Kesimpulan}

1. Ketersediaan atau produksi cabai merah rata-rata 5 tahun terakhir 2.150 ton, sedangkan kebutuhan cabai merah 19.866 ton sehingga terjadi minus 17.716 ton, kekurangannya dipasok dari Rembang dan Jawa Timur. Oleh sebab itu Kabupaten Pati belum mencapai ketahanan pangan di komoditas cabai merah.

2. Perkembangan harga cabai selama tahun 2014 (Januari-Desember) mengalami fluktuasi yang sangat signifikan sehingga sulit diprediksi, hal ini terlihat pada awal tahun harganya Rp26.975/kg, pertengahan tahun Rp8.276 kg dan pada akhir tahun mencapai Rp53.901/kg.

\section{Saran}

1. Melihat komoditas cabai merah yang belum mencapai ketahanan pangan di Kabupaten Pati, sementara terdapat potensi lahan untuk budidaya cabai merah, maka perlu upaya mendorong petani melalui kegiatan penyuluhan untuk membudidayakan cabai merah karena komoditas yang satu ini prospektif menguntungkan dan banyak dibutuhkan; 
2. Perlu upaya menstabilkan harga cabai dengan memperbaiki manajemen rantai pasokan dan pemasaran dengan melibatkan pemerintah.

\section{DAFTAR PUSTAKA}

Badan Pusat Statistik Kabupaten Pati. 2012. Pati dalam Angka Tahun 2011. Pati.

2014. Pati dalam Angka Tahun 2013. Pati.

BPTP Jawa Tengah. 2010. Budidaya dan Pascapanen Cabai Merah (Capsicum annuum L.). Badan Penelitian dan Pengembangan Pertanian. Balai Pengkajian Teknologi Pertanian Jawa Tengah.

Bappenas. 2013. Studi Pendahuluan Rencana Pembangunan Jangka Menengah Nasional (RPJMN) Bidang Pangan dan Pertanian 2015-2019. Direktorat Pangan dan Pertanian Kementerian Perencanaan Pembangunan Nasional.

Harpenas, A., R. Dermawan. 2010. Budidaya Cabai Unggul. Jakarta: Penebar Swadaya.

Ibrahim, H. M. Y. 2003. Studi Kelayakan - Cetakan II. Jakarta: PT. Rineka Cipta.

Leedy, P. D., J. E. Ormrod. 2005. Practical Research: Planning and Design Research ( $8^{\text {th }}$ edition). Ohio: Pearson Merrill Prentice Hall: 145187.

Nasir. 2003. Metode Penelitian. Jakarta: Ghalia Indonesia.

Nurfalach, D. R. 2010. Budidaya Tanaman Cabai Merah (Capsicum annum l.) di UPTD Perbibitan Tanaman Hortikultura Desa Pakopen Kecamatan Bandungan Kabupaten Semarang. Tugas Akhir. Program DIII Agribisnis. Surakarta: Universitas Sebelas Maret.
Peraturan Pemerintah Nomor 68 Tahun 2002, tentang Ketahanan Pangan.

Sutrisno. 2014. Ketersediaan Pangan Kedelai (Glicine max) di Kabupaten Pati. Jurnal Litbang 10(1): 15-23.

.2014. Rantai Pasokan dan Pemasaran Pangan di Kabupaten Pati. Laporan Hasil Penelitian. Pati: Kantor Ketahanan Pangan Kab. Pati.

2013. Pasokan Pangan. Pati: CV. Mitra Sejati.

Susenas. 2012. Konsumsi Rata-rata per Kapita Setahun Beberapa Bahan Makanan di Indonesia, 2008-2012.

Syarief., Hidayat., Hardinsyah., Sumali. 1999. Membenahi Konsep Ketahanan Pangan Indonesia. Pembangunan Gizi dan Pangan Dari Perspektif Kemandirian Lokal. Perhimpunan Peminat Gizi dan Pangan (PERGIZI).

Tjahjadi, N. 1991. Bertanam Cabai. Yogyakarta: Kanisius.

Undang-Undang Nomor 18 Tahun 2012 tentang Pangan.

\section{BIODATA PENULIS}

Sutrisno, lahir 12 Januari 1956 di kota Kudus Jawa Tengah. Pendidikan Magister Manajemen dari Universitas Muhamadiyah Surakarta. Saat ini bekerja sebagai Peneliti Madya di Kantor Penelitian dan Pengembangan Kabupaten Pati. 